\title{
Effect of Cyclic Loads on Structural Damage of Rocket Propellant Grain
}

\author{
Nikola Gligorijević ${ }^{1)}$ \\ Vesna Rodic ${ }^{1)}$ \\ Bojan Pavković ${ }^{1)}$ \\ Jovica Bogdanov ${ }^{2}$ \\ Saša Živković ${ }^{1)}$ \\ Zoran Bajić ${ }^{2)}$
}

\begin{abstract}
Rocket motor propellant grain, cast or bonded into the motor chamber or solid coating, is exposed to various loads during its service life. Rocket propellant is a viscoelastic material, whose mechanical properties strongly depend on temperature and strain rate. Application of cyclic loads, primarily thermal, onto a rocket motor on the field stock, may cause an undesirable mechanical damage of the grain. Over time, after long storage, it may grow up and lead to the grain failure. One of the ways for evaluation of this phenomenon is to determine a cumulative damage law. In this example, this law has been evaluated for hydroxy terminated polybutadiene (HTPB) composite rocket propellant by exposing a number of specimens to different long term stress levels. Using this law, it is possible to calculate a probability of failure and time distribution of the structural reliability of the grain in order to determine the useful life. Besides, the analysis has shown that there is a possible correlation between tensile strength of the propellant and the cumulative damage law. This fact can be used instead of carrying a longterm experiment for the exact determination of the law
\end{abstract}

Key words: rocket motor, propellant grain, mechanical properties, structural analysis, cumulative damage, service life.

\section{Introduction}

$\mathrm{O}$ VER the service life of a rocket motor, during handling, transportation, storage, and finally its ignition and work, the viscoelastic propellant grain is exposed to various loads which may result in its damage.

For viscoelastic material, whose mechanical properties are dependent on temperature and strain rate, various external loads cause different strain rates and consequently, different values of ultimate stresses and allowable strains of the viscoelastic material. It is not possible in structural analysis to define the equivalent tensile strength or allowable strain for comparison with an equivalent stress due to the simultaneous effect of different loads, because the ultimate values depend on the conditions of load action. Each type of load acts differently onto a viscoelastic body and has to be considered separately. Theoretically, for linear-viscoelastic body, the application of convolution principle [1] is the most acceptable.

Each individual load causes a certain damage fraction that, simplified, represents the ratio between actual and ultimate stress. If these values are time dependent, then the damage fraction is also time dependent:

$$
d(t)=\frac{\sigma_{i}(t)}{\sigma_{m}(t)}
$$

The term "damage" usually indicates non-reversible changes. But it is not always the case. The problem is in insufficiently defined terminology when considering the safety factor (or margin of safety) of viscoelastic bodies.
If the actual stress is much lower than the ultimate stress, there will be no permanent damage, so the ratio of the two values in the expression (1) will be less than unit. When the effect of load stops, the stress in the viscoelastic body will relax and no permanent damage will occur.

In the papers [2,3], this terminology is considered in more detail. Instead of the term "damage fraction", the term "current damage" is used. "It represents only the part of the total propellant grain response that is required to cause failure". This topic was discussed in [2].

Some loads may act for some time and then become too small or they can completely disappear. Should the value of "current damage" be greater than 1, it would mean that the grain would most likely fail. But if the "current damage" is less than 1, then no failure will occur.

When there are several simultaneous different loads, each of them causes its own current damage. The total current damage, according to the principle of convolution, is equal to their sum.

$$
d(t)=d_{1}(t)+d_{2}(t)+\ldots+d_{n}(t)
$$

If their sum is greater than 1 , this again means that there is a high probability of failure.

When the loads disappear the current damage will also disappear and the effects of the loads might be completely relaxed. Some damage might remain, but it would be negligible if the loads acted for a short period.

\footnotetext{
1) Military Technical Institute (VTI), Ratka Resanovića 1, 11132 Belgrade, SERBIA

2) University of Defence, Military Academy, Pavla Jurišića Šturma 33, 11000 Belgrade, SERBIA

Correspondence to: Nikola Gligorijević; e-mail: nikola.gligorijevic@gmail.com
} 
There are other types of loads whose intensity is not so high to lead to a rapid failure of the grain, but their effect may take a long time, so the stresses cannot be relaxed. Their longterm effect may cause so-called "cumulative damage". This term differs from "current damage" and represents all accumulated damage made by previous loads, especially by cyclic effect of high frequency $[4,5]$.

The most important cyclical loads are due to the effect of ambient temperature and they must always be considered, since they continuously act onto every case bonded propellant grain (Fig.1), from the moment the grain is made. In addition, if there are some other cyclic loads, which depends on specific conditions, they also have to be considered by structural analysis.

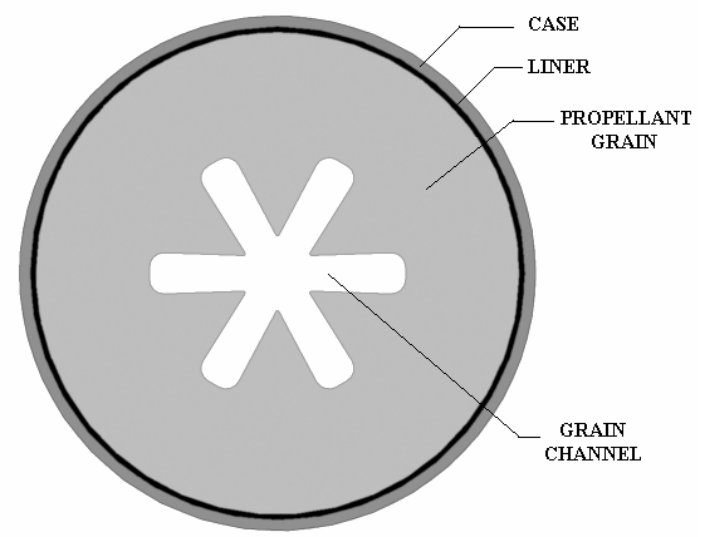

Figure 1. Case bonded propellant grain

Thermal load arises due to the difference between ambient temperature and zero stress temperature in the propellant grain.

$$
\Delta T=T_{a}-T_{0}
$$

\section{$T_{a} \quad$ - Ambient temperature}

$T_{0} \quad$ - Zero-stress temperature

Permanent damage due to the long-term effect of small continuous loads is rarely considered in literature. One of the authors who pay attention on this feature is Heller [4, 6, 7]. His model for defining the mechanical properties of viscoelastic material during long-term storage includes natural (chemical) aging and the weakening due to the effect of cumulative damage under the environmental loads, equations 4 and 5:

$$
\begin{gathered}
\sigma_{m}(t)=\sigma_{m 0} \cdot \eta_{\sigma}(t) \cdot[1-D(t)] \\
\varepsilon_{m}(t)=\varepsilon_{m 0} \cdot \eta_{\varepsilon}(t) \cdot[1-D(t)]
\end{gathered}
$$

$\sigma_{m}, \varepsilon_{m}$ - tensile strength, allowable strain

$t$ - Arbitrary time

$\sigma_{m 0}, \varepsilon_{m 0}$ - initial values for virgin propellant

$\eta_{\sigma}, \eta_{\varepsilon} \quad$ - aging factors

$1-D$ - Cumulative damage

Time dependence of the aging factor $\eta(t)$ is a property of the polymeric material and can be determined by periodic tensile tests $[2,6,8,9]$.

It is usually considered that the values of the factor $(D)$, that define the accumulated damage, are too small for fresh propellant, in the initial period after production.

According to Heller $[4,6]$, during the first ten years of storage this value does not exceed $10^{-3}$, so the last factor in the expressions (4) and (5) is close to unit (0.999) and does not affect the values of tensile strength and allowable strain. Similarly, the work [10] also ignores the effect of damage accumulation in the initial storage period.

However, based on our experience $[2,8,11]$ this factor can be high even in the initial period. It depends on variation of the ambient temperature, geometrical characteristics of the grain (Fig.1), mechanical properties of the propellant and case, and especially on the difference between thermal expansion coefficients of the propellant and case.

In most cases, after the case bonded grain is made [12], the value of the accumulated damage in the initial period is very small and it cannot be measured or detected [1]. Although each temperature cycle can be very small, almost negligible, it leads to a new damage.

When the number of daily temperature cycles becomes significantly high, due to prolonged storage, it is possible to make a mathematical assessment of the total accumulated damage if the cumulative damage law is known, according to the Miner's fatigue law for metals [13].

This paper presents the process of estimating the effect of cyclic loads on deterioration of the mechanical properties of rocket propellant, which reduces the reliability of the propellant grain and the service life of the rocket motor.

The analysis of cyclic loads is shown on the example of temperature load and consists of the following steps:

1. Time dependence of environmental temperature;

2. Time distribution of the stresses, strains and current damages in the characteristic points of the propellant grain due to the effect of temperature.

3. "Cumulative damage law" for viscoelastic rocket propellant, which allows making a numerical assessment of permanent damages in the grain.

4. Calculation of the time distribution of cumulative damage due to the effects of all previous loads;

5. Time distribution of the probability of failure due to accumulation of damage;

6. Time dependence of propellant grain reliability;

7. Determination of useful life.

\section{Temperature load analysis}

During an earlier study $[2,8,11]$, a mathematical model for the time distribution of the temperature was formed.

Real data on an annual temperature change in Belgrade were used from the Serbian Republic Hydro-Meteorological Service [14] (Fig.2).

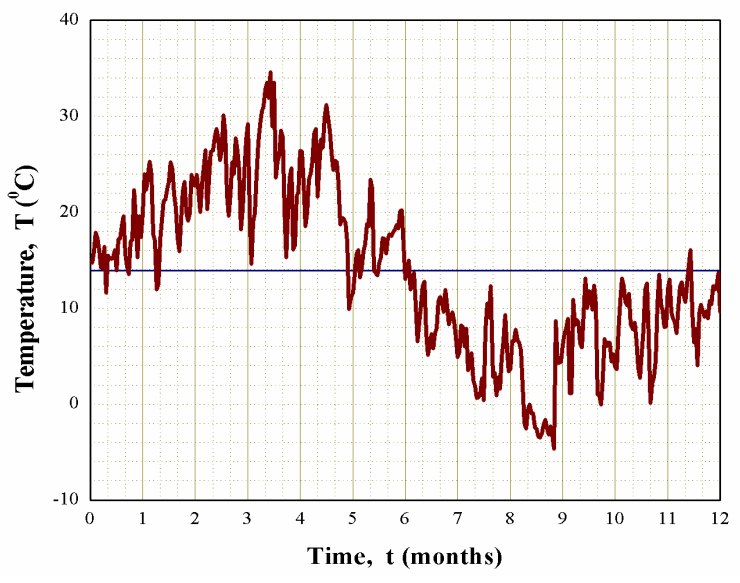

Figure 2. Temperature changes over the year 
Since it is a climate zone with four seasons, this one-year sample represents a real temperature change. This curve should be presented in the form of mathematical formula for further analysis. For better visibility, the beginning of the curve is set to the spring equinox, so that the approximate cyclic temperature distribution over the year is seen.

Temperature changes over one year period are presented in the form of a mathematical function. On the diagram (Fig.2) seasonal and daily cyclical variations of temperature are seen. Occasional temperature jumps and drops (thermal noise) are also presented as cyclical, so the total temperature is shown as the sum of cyclical changes $[2,8,11]$.

$$
T(t)=\sum A_{i}(t) \cdot \sin \left(\omega_{i} \cdot t\right)
$$

Fig. 3 shows the temperature change in the first quarter after spring equinox, according to a mathematical model that predicts temperature jumps every week.

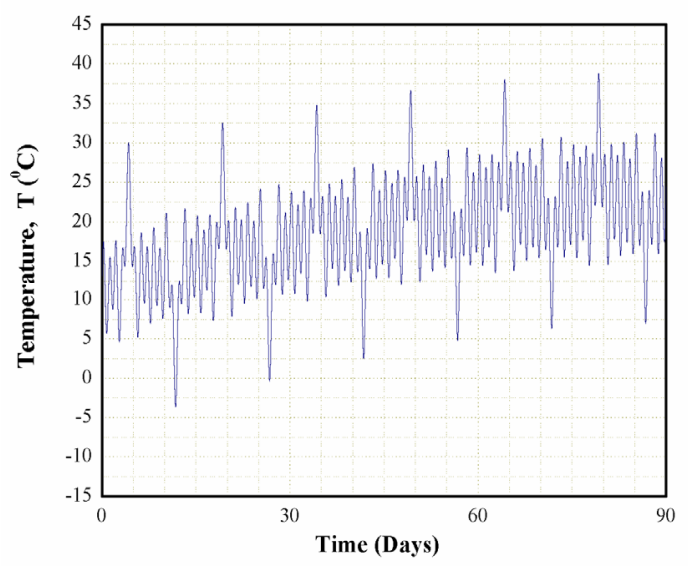

Figure 3. Simulation of temperature distribution over a period of 90 days

For each single field stock, the results of cumulative damage calculations can be very different [4].

The zero-stress temperature $\left(T_{0}\right)$ is about $15^{\circ} \mathrm{C}$ above the temperature of the propellant casting [15]. The casting temperature is usually about $65^{\circ} \mathrm{C}$, so the zero stress temperature is about $80^{\circ} \mathrm{C}$. When the rocket is stored, environmental temperature is lower and the case bonded grain is always under the thermal stress due to the temperature difference between ambient and zero-stress temperature. Large difference between coefficients of thermal expansion of the motor case and propellant creates high stresses. Since the ambient temperature oscillates, the thermal stresses also oscillate. Long-term oscillations can cause significant grain damage.

$$
\Delta T(t)=T_{a}(t)-T_{0}
$$

\section{$T_{a} \quad$ - Ambient temperature \\ $T_{0} \quad$ - Zero-stress temperature}

\section{Stress and strain analysis}

Stresses and strains in the propellant grain depend on the type of load (pressure, temperature difference, acceleration, etc.), strain rate, ambient temperature, type of propellant and its physical properties, material of the case and geometry of the grain. A simplified form of the expressions is:

$$
\sigma, \varepsilon=f\left(\Delta T, t / a_{T}, \phi_{p}, \phi_{c}, r\right)
$$

$$
\begin{array}{ll}
\sigma & \text { - Stress } \\
\varepsilon & \text { - Strain } \\
r & \text { - Grain geometry } \\
\phi_{p} & \text { - Propellant properties } \\
\phi_{c} & \text { - Case properties }
\end{array}
$$

The good circumstance is that the rocket motor is usually the axially symmetric body, so the equations for the stress and strain are relatively simple in the cylindrical coordinate system.

Expressions in closed form for thermal stresses and strains in the characteristic points of the propellant grain, for example in the hollow-channel or in the bond between propellant and case, can be easily found in literature for different shapes of propellant grains [2, 6, 11, 15-17].

For example, the relevant value for the structural analysis is tangential component of the strain ("hoop strain") due to the effect of temperature difference in the of the grain:

$$
\varepsilon_{\theta}(t)=\left\{\alpha(1+v)-2(1-v) M^{2} K \cdot \Phi\right\} \cdot \Delta T(t)
$$

$$
\begin{array}{ll}
\alpha & \text { - Coefficient of propellant thermal expansion } \\
v & \text { - Poisson's ratio } \\
M & \text { - Outer/internal grain-diameter ratio } \\
K & \text { - Stress concentration factor } \\
\Phi & \text { - Factor that depend on grain geometry and } \\
& \text { propellant and case physical properties }
\end{array}
$$

For propellant grains with a star perforated channel, the expressions for the hollow channel should be corrected with stress-concentration factors introduced.

Since the propellant grain is viscoelastic body, none of the criteria used in elastic analysis is good enough to assess a reliable margin of safety. It is recommended for an analyst to use the strain criterion in the grain channel, better than the stress comparison to the ultimate strength.

\section{Cumulative damage law}

"Miner's law" is one of the most used to describe material fatigue under different loads. It is usually applied to elastic materials such as metals, but analogously it can also be used for viscoelastic materials, like composite rocket propellant.

Miner-Palmgren theory [13] is used for damage evaluation of the bodies exposed to cyclic loads of different amplitudes over a long period. Each of these individual loads causes the "body damage fraction" $D_{i}(t)$, defined as the ratio of number of cycles acted on the body and the number of cycles of the same amplitude needed to lead to the failure [1].

$$
D_{i}(t)=\frac{n_{k}}{N_{k}}
$$

$$
\begin{array}{ll}
n_{k} & \text { - Number of cycles at the } k^{\text {th }} \text { load level } \\
N_{k} & \text { - Number of cycles needed to cause the failure at the } \\
& k^{\text {th }} \text { load level }
\end{array}
$$

Similarly, this law can be presented through the ratio between time of the body exposure to a constant load and the time needed to achieve failure at the same constant load.

$$
D_{i}(t)=\frac{\Delta t_{i}}{t_{f i}}
$$

$\Delta t_{i} \quad$ - Time of exposure to the $i^{t h}$ load level

$t_{f i} \quad$ - Time to failure at the $i^{\text {th }}$ load level

This form is more acceptable for structural analysis of the rocket motor propellant grain. Linear cumulative damage law is recommended $[1,18,19]$. 
When the whole load history is covered and the effect of all individual loads are assembled, the total damage is obtained:

$$
D(t)=\sum_{i=1}^{i=m} D_{i}(t)
$$

\section{$m \quad$ - Total number of different loads $D(t)$ - Damage}

When the total damage reaches unit, it is assumed that the failure will occur [1]. In the same reference, methodology based on replicate failure tests, statistical processing and calculation of probability of failure is recommended. The procedure is described in detail in the reference [20].

Determination of partial damage fractions (11) requires the relationship between stress and time to failure. This means that it is necessary to determine the times to failure for the stresses of different intensities.

Dependence between applied stress $\left(\sigma_{i}\right)$ and time to failure $\left(t_{f i}\right)$ has been determined in a previous study in the Military Technical Institute (VTI), Belgrade [2, 11], for a HTPB based composite rocket propellant, in order to analyze the damage of a real propellant grain for an anti-hail rocket. The functional dependence between the two is called "cumulative damage law". In the literature $[1,19]$, a power function is recommended:

$$
t_{f}=M \cdot \sigma^{-N}
$$

Since the appearance of material failure depends not only on time, but also on temperature, the expression (13) needs to be expanded. Mechanical properties of the rocket propellant as a viscoelastic material are strongly dependent both on strain rate and temperature $[1,15,18,21,22]$.

Temperature dependence is important in the structural analysis of viscoelastic materials. In the aforementioned literature, as well as in other references [17, 22, 23], deviations of mechanical properties relative to the reference temperature are described by the "time-temperature shift factor" $a_{T}=f(T)$. Since the mechanical properties can vary with time and temperature up to three orders of magnitude, for their easier display in diagrams, the factor $\left(a_{T}\right)$ is usually represented by regression curve in logarithmic form:

$$
a_{T}(T)=-C_{1} \cdot \frac{T-T_{0}}{C_{2}+T-T_{0}}
$$

$T$ - Arbitrary temperature

$T_{0} \quad$ - Reference temperature

$C_{1}, C_{2}$ - Constants

For a whole range of pure polymers, in the range $T_{\mathrm{g}} \pm 50^{\circ} \mathrm{C}$, where $\left(T_{g}\right)$ is the glass transition temperature, the constants $C_{1}, C_{2}$ have universal values.

The polymeric basis of the composite propellant dominantly affects its mechanical properties, but there is a large amount of a powdered oxidizer in its composition and it cannot be treated as a pure polymer. In addition, the rocket propellant has to be used in a different temperature range, so the universal values for the constants $C_{1}, C_{2}$ cannot be used [23].

The experimental determination of $\left(a_{T}\right)$ factor is necessary for all different propellant compositions. In the Department for Energetic Materials in VTI, this procedure has been applied for more than 35 years. These results are used in the rocket sector in the process of the structural analysis of rocket motors.
Experimental procedure for determining the factor $\left(a_{T}\right)$ is detailed in our papers $[2,3]$.

Dependence on strain rate is practically dependence on time. This means that the propellant properties depend on temperature and time. It has been shown that there is a simple functional dependence between time and temperature. It is therefore possible to present the time and temperature dependence of propellant mechanical properties only as a dependence on single variable, called the "reduced time".

$$
\xi=\frac{t}{a_{T}(T)}
$$

$\xi \quad$ - reduced time

$t \quad$ - time

$a_{T}(T)$ time-temperature shift factor

Finally, for the cumulative damage analysis of a propellant grain, for the given propellant, a relationship between reduced failure times $\left(\xi_{f i}\right)$ and loads $\left(\sigma_{i}\right)$ has to be estimated.

The expression (13) becomes:

$$
\frac{t_{f}}{a_{T}}=M \cdot \sigma^{-N}
$$

In order to evaluate parameters in the expression (16) it is recommended $[4,6]$, to make tension tests with constant loading. For the given propellant, the failure times corresponding to different applied stresses have been measured. A large number of tests with different loads have been performed (Fig.4). From the point of expected large scattering of measurement results, the loads were randomly chosen in order to prevent subjectivity. Each constant load was carried out with a rather large sample consisting of 8-10 specimens, due to the large scatter and statistical processing.

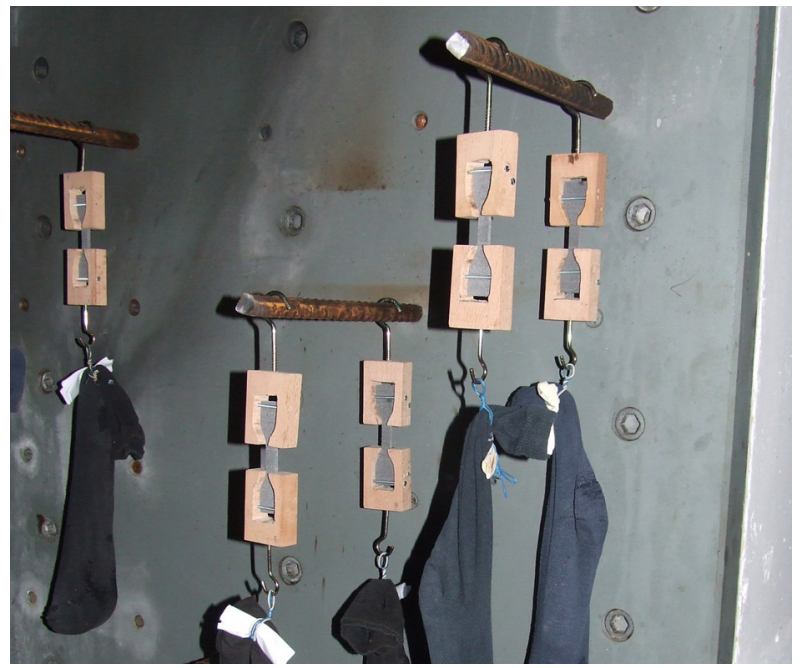

Figure 4. Constant load tests

The tested propellant was previously used for the small anti-hail rocket grains. The cracks appeared in the star channel of the $80 \%$ of the series of propellant grains, only 3-4 months after the production (Fig.5).

The fact that the whole series of grains had a failure has shown that it was not a random occurrence. We have got an opportunity to obtain the law of cumulative damage, and to compare the results of structural analysis with the unexpected results of the grain failure obtained with an important sample of real propellant grains. This result was used to test the model for structural analysis and for estimating the method for determination of reliability. 


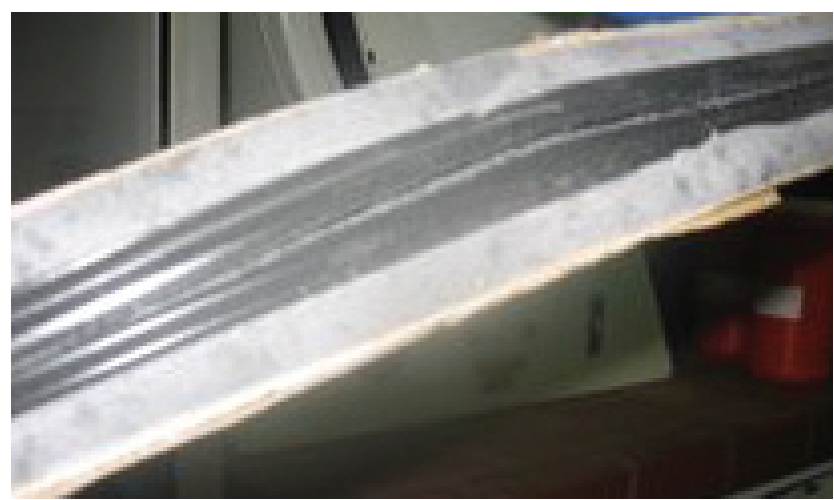

Figure 5. Cracks in the grain channel

The amount of test results with propellant specimen was too large for this format. They are not shown here, but they are attached to the work as a supplement. A part of the results has been shown in [2].

A number of constant loads were applied (Fig.4), not too large to cause a rapid failure, but to provide long-term tests of different duration.

Failure times $\left(t_{f i}\right)$ and daily temperatures $(T)$ were measured. A large number of tests lasted up to several months, to provide enough data on long-term load behavior. Some of the results are shown in the diagram, Fig.6.

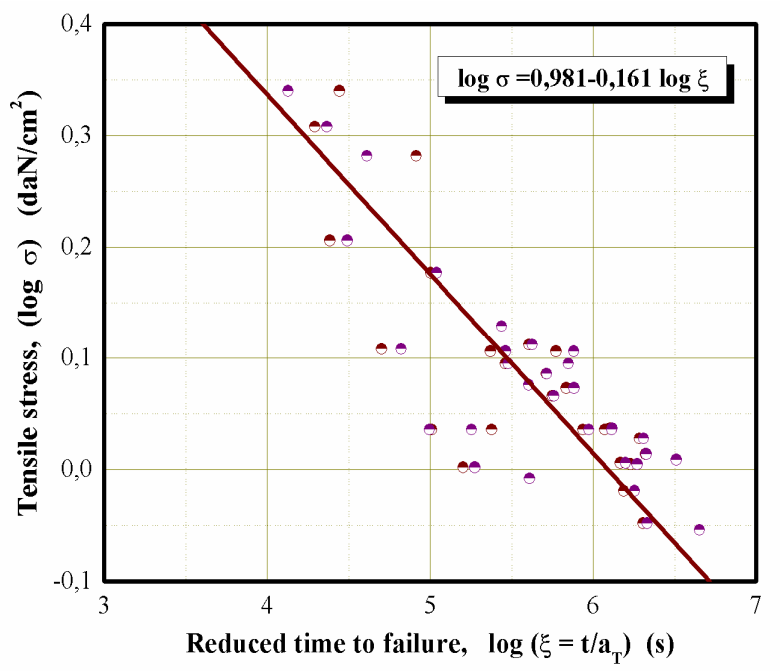

Figure 6. Tensile stress vs. reduced failure time

In Fig.6 a linear relationship is seen between the reducedtime to failure and given tensile stress. It seems that the scattering of the results is quite high, but this is the result of various external influences. This relates to strong daily and seasonal temperature variations during the test, differences in sample structures, small inequalities in the load distributions, etc.

Scattering of test points in the diagram (Fig.6) does not affect much the final result of the structural analysis because the reduced failure time $(\xi)$ is used as a statistical variable. Its deviations are taken into account, and the obtained cumulative damage law is applied in an analysis whose methodology includes a statistical approach in evaluating the probability of grain failure [24], which takes all dispersions into account.

All the features in the process of determination the cumulative damage law (eq.16) were treated as statistical variables. In the paper [6], we have also seen a large scattering of points in the similar experiment, based on the coefficient of variation.
It is customary to adopt for further calculation the regression line obtained by fitting the given field of points. This result may be named "the primary regression". This regression is based on the least squares method, which makes the smallest sum of squares of distances between individual points and the regression curve. These distances are measured vertically along the ordinate.

If the places of ordinate and abscissa are changed the distances shall be measured horizontally along the abscissa and this will lead to a different result.

If the scattering in the field was smaller, the two regression lines would be closer. The best solution is to combine and adopt an average solution.

The final expression for regression line is:

$$
\log \sigma=0,981-0,161 \cdot \log \left(\frac{t_{f}}{a_{T}}\right)
$$

Then, the requested term (16) for the cumulative damage law has the following form [2]:

$$
\frac{t_{f}}{a_{T}}=M \cdot \sigma^{-N}=1.239 \cdot 10^{6} \cdot \sigma^{-6.21}
$$

The described procedure for determining the law (18) is quite simple. The basic problem is the long duration of the test. During the test it is necessary to monitor each individual propellant specimen at certain intervals. In addition to the monitoring and recording ambient temperature, it is necessary to maintain the humidity in the test room within the required limits.

The expression (18) was used in further analysis. However, it is very important that during the processing of these results an interesting correlation between the "cumulative damage law" and the tensile strength master curve of the propellant was observed, which provides a fairly good estimation in some subsequent cases of rocket motor design.

\section{Time dependence of damages in the critical zones of the grain}

When the power law (18) is determined, it is possible to calculate the value of total damage by adding up all individual damages due to the previous loads. If $i$-th load acted during a period $\left(d t_{i}\right)$ the following damage occurred:

$$
D_{i}(t)=\int \frac{d t_{i}}{t_{f i}}
$$

Using the relation (16) between time to failure $\left(t_{f i}\right)$ and tensile stress $\sigma(t)$ the following expression is obtained:

$$
D_{i}(t)=\int \frac{d t_{i} \cdot \sigma(t)^{N}}{a_{T i} \cdot M}
$$

When the temperature change is known, and therefore the temperature difference, it is possible to determine the stress distribution, using expressions from the elastic analysis. Thus, all the features in expression (20) are known. For example, in the star-perforated grain, the equations for calculation tangential (hoop) stress in the channel are obtained from the same source as the equations for strain (eq.9). The stresses depend on dimensions and shape of the grain, and material, dimensions and physical properties of the case. 
This consideration implies that the dependence of ultimate mechanical properties of the propellant $\sigma_{m}(t), \varepsilon_{m}(t)$ on the natural aging $\eta(t)$ has already been determined.

When the time distribution of the total accumulated damage $D(t)$ is determined, it is possible to completely define the time change of the tensile strength $\sigma_{m}(t)$ and allowable strain $\varepsilon_{m}(t)$ of the propellant, according to the expressions (4) and (5). Thus, at any given time it is possible to determine the value of the current damage $d_{i}(t)$, in accordance with both criteria (stress and strain):

$$
\begin{gathered}
{\left[d_{i}(t)\right]_{\varepsilon}=\frac{\varepsilon(t)}{\varepsilon_{m}(t)}} \\
{\left[d_{i}(t)\right]_{\sigma}=\frac{\sigma(t)}{\sigma_{m}(t)}}
\end{gathered}
$$

The results obtained on the basis of the two criteria differ. This is expected, because the viscoelastic material does not have a completely linear relationship between stress and strain. The reference [1] recommends as dominant the strain criterion in the grain channel and the stress criterion in the grain-case bonds. However, it may be better to adopt a criterion that gives a less margin of safety in the analysis, as it leads to greater reliability of the service life assessment.

In Fig.7, for one of the versions of anti-hail propellant grain, the first-year distribution of "current damage" due to the temperature load is shown, according to both criteria (stress and strain) $[2,11]$. The situation in the channel zone of the grain was considered. This zone is critical because there is a high stress concentration due to the shape. This distribution of the current damage should be monitored over the entire service life, starting from the moment of propellant grain production. The peaks on the diagrams are due to introduction a temperature noise of high intensity into the mathematical model of temperature change.

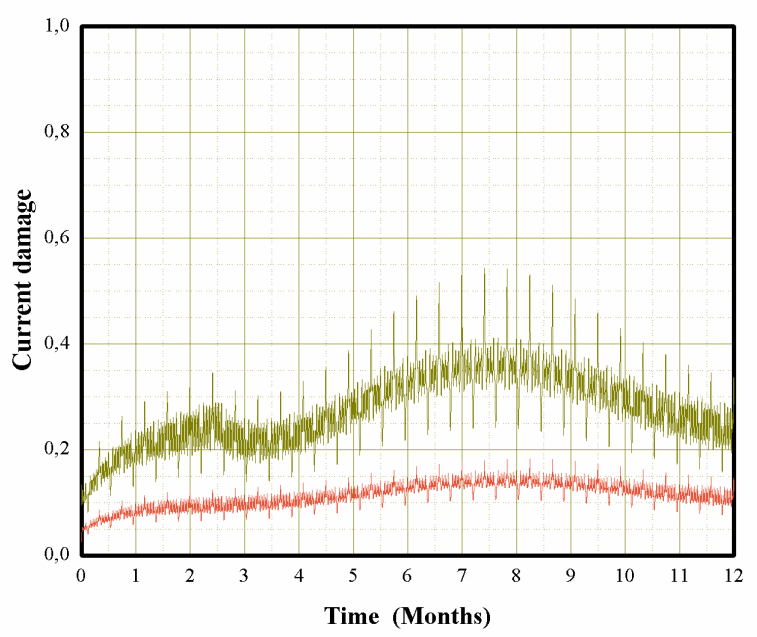

Figure 7. Dammage fraction vs time

In the considered case, the maximum calculated value of current damage hardly exceeds 0.5 . This value is obtained according to the criterion of actual-stress comparison with tensile strength. According to the theory of elasticity and the recommendation for viscoelastic material, in the channel the strain criterion should be applied. This result is even more favorable, since the current damage does not exceed 0.2 . Large differences are due to the fact that there is no linear dependence between ultimate strength and allowable strain when the temperature and strain rate change.
It is important here that current damage (according to both criteria) is far from the unit that represents the value needed to achieve failure. This indicates that current damage was not sufficient to cause grain failure.

Both values of current damage are higher than real, because the peaks in the diagram are caused by too high temperature noise, that is introduced in order to make a safer assessment. Safety factor is as a reciprocal value of current damage. Its minimum value is close to 2 , indicating a reliable design.

In this example, the large difference between ambient temperature and zero-stress temperature is not sufficient to cause failure. Propellant strength is high and the grain can withstand the impact of the current temperature difference.

Concentrated loads can reduce safety factor. They should be monitored only at the time of operation or for a short period after their action, until the stresses relax. Such loads may arise as a result of transport, handling, short aerodynamic heating and acceleration in a combat flight, during which the rocket motor has not been activated, etc.

Later, in order to determine the overall effect of previous loads, it is not necessary to consider concentrated loads whose effect was short. If these loads were not too large to cause grain failure, the generated stresses relax afterwards and their impact on the propellant grain is finally negligible.

However, viscoelastic body behaves as if it remembers previous loads that slowly accumulate damage in the body. The damages may become dominant after some time.

The previous, accumulated damage can be considered in a different way in relation to the classic theory of elasticity. When the time distribution $D(t)$ of the cumulative damage is determined, it is possible to apply a different methodology [4] which found its confirmation in our analysis of the failure of anti-hail rocket propellant grains $[2,8,11,24]$.

\section{Probability of failure and grain reliability}

When the time distribution $D(t)$ is known, it is possible to define damage fractions $D_{i}(t)$ that occurred in all arbitrary time intervals. Daily intervals are very important because they correspond to one temperature sinus cycle.

If the value of one-day damage fraction for an arbitrary day in the service life of the rocket motor is marked as $D_{i}(t)$ the calculation will show that this value is very low. almost negligible.

But if the period before the rocket motor is used is too long, these low values $D_{i}(t)$ are accumulating and the damage can go up too much.

Heller and Zibdeh [4, 7] recommended probabilistic methodology for evaluation the propellant grain reliability.

It is necessary to consider reliability in critical zones of the grain. For example, an analyst at first has to consider the area in the star shaped channel, because there is a very high stress concentration. Tangential strain ("hoop strain") is the most relevant feature in the propellant grain channel. It is necessary to define the probability that the allowable strain of the propellant $\left(\varepsilon_{m}\right)$ is less than the actual hoop strain $\left(\varepsilon_{\theta}\right)$. At the same time, it is also the probability of the failure $\left(P_{f \varepsilon}\right)$ in the grain channel.

$$
\begin{gathered}
P_{f \varepsilon}=P\left(\varepsilon_{m} \leq \varepsilon_{\theta}\right) \\
P_{f \varepsilon}=P\left(\varepsilon_{m}-\varepsilon_{\theta} \leq 0\right)
\end{gathered}
$$


Both allowable and applied strains in the grain channel are random variables, as well as their difference. The same applies to the stresses in the bond between grain and case.

The probability density function of the difference of two random variables is a convolution integral. In the paper [24], a more detailed explanation of the procedure for numerical determination of these probabilities is given. The simple use of the computer program "Mathcad" is explained.

Similarly, probability of a failure in the bond $\left(P_{f \sigma}\right)$ between the grain and the motor chamber has to be considered. It is recommended in this zone to use the stress criterion $[1,18]$ and to compare radial stress in the bond $\left(\sigma_{r}\right)$ and propellant tensile strength $\left(\sigma_{m}\right)$.

$$
\begin{gathered}
P_{f \sigma}=P\left(\sigma_{m} \leq \sigma_{r}\right) \\
P_{f \sigma}=P\left(\sigma_{m}-\sigma_{r} \leq 0\right)
\end{gathered}
$$

Naturally, when the propellant grain is designed well, this probability of failure should be very low.

This approach is based on the determination of statistical parameters for the real loads and stresses, as well as for the ultimate propellant properties.

All other zones in the grain are less loaded and in this example they can be neglected.

Probability of failure is equal to the probability that both differences, in the channel and in the bond, are equal or less than zero. Probability of the union of two events (grain failure in the channel and de-bonding the grain) may be approximated by the sum of their single probabilities, because those are independent events.

$$
\begin{gathered}
P_{f}=P\left(\sigma_{m} \leq \sigma_{r} \cup \varepsilon_{m} \leq \varepsilon_{\theta}\right) \\
P_{f}=P\left(\sigma_{m} \leq \sigma_{r}\right) \cup P\left(\varepsilon_{m} \leq \varepsilon_{\theta}\right) \\
P_{f}=P\left(\sigma_{m}-\sigma_{r} \leq 0\right)+P\left(\varepsilon_{m}-\varepsilon_{\theta} \leq 0\right) \\
P_{f}=P_{f \sigma}+P_{f \theta}
\end{gathered}
$$

The probability (30) that there will be no failure on a strictly determined day of the year, is a time dependent feature, which varies along with the variation of the ambient temperature. It is needed to get the values of $\left(P_{f}\right)$ at the end of every temperature cycle. At the end of the first one-day cycle, the probability of failure can be marked with index (1), and so on for each subsequent day. The grain failure is the opposite event to the grain sustainability:

$$
R_{1}=1-\left(P_{f}\right)_{1}
$$

After ( $n$ ) cycles (n-days), using the multiplication rule of probabilities, the reliability is equal to the probability of surviving all the previous cycles, and it is given as an $n$-fold production:

$$
\begin{gathered}
R_{n}=\left(1-P_{f_{1}}\right) \cdot\left(1-P_{f_{2}}\right) \cdot \ldots \cdot\left(1-P_{f_{n}}\right) \\
R_{n}=\prod_{i=1}^{i=n}\left(1-P_{f_{i}}\right)
\end{gathered}
$$

It was this kind of analysis that confirmed the occurrence of failure in the propellant grain channels of a whole series of antihail missiles. It was very likely that this was due to accumulated damage, caused by cyclic temperature load, although this occurred at the very beginning of service life, only few months after production $[2,11]$.

The result of the analysis, based on the principles of the theory of elasticity, was different (Fig.7). It showed that the current damage was relatively small and the safety factors were high enough.

In the same example, the impact of cumulative damage is shown (Fig.8). Five years distribution of the probability of failure is displayed. The value does not exceed 0.4 .

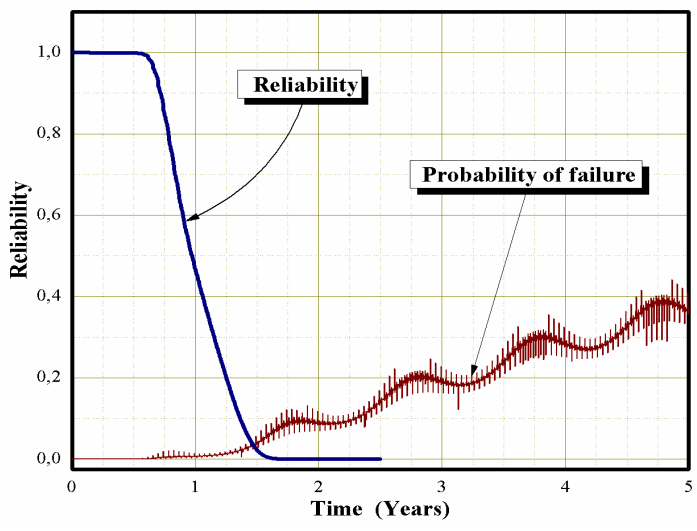

Figure 8. Reliability and probability of the grain failure

However, the reliability of the propellant grain drops to 0.5 after just one year. The reasons are the large difference in the mechanical properties of the viscoelastic propellant and very rigid chamber, difference in thermal expansion coefficients that is greater than 10 times, and the unfavorable ratio of geometric parameters. All these facts can be predicted in advance, using the appropriate analysis at the design stage.

\section{Propellant grain service life}

Time distribution of the reliability in Fig. 8 indicates that the lifetime should be completed when the reliability falls below the given limit and then the motors have to be thrown out from use. For missiles of different purposes, the values of the minimum reliability and other safety parameters should be defined depending on the requirements of the user.

In Fig.9, there is a simple graphic presentation how the mechanical properties of the propellant become increasingly weaker and can no longer withstand external loads.

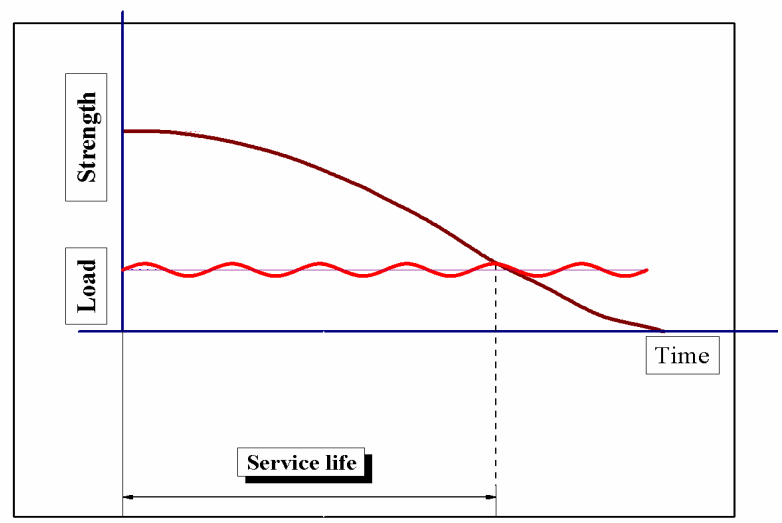

Figure 9. Service life

When each of these features (load distribution, ultimate strength, temperature, strain rate etc.) is considered as a statistical variable, it can be explained that there is a certain probability of failure not only at the end of service life, but also at the very beginning of the use, but probability of this phenomenon for the fresh propellant is quite small. 


\section{Cumulative damage rule}

In order to analyze the impact of the long-term cyclic load, whose amplitude at the moment of action does not lead to the current failure, but affects small permanent damage fractions, it is necessary to know the cumulative damage law. Determination of this function requires at least few months of experimental work. This experiment is simple but it lasts for a long time.

However, in the phase of a new rocket motor design, in the absence of necessary data in advance, before the propellant composition is chosen, it is possible to make an approximate analysis.

The results of the long-range constant stress test have indicated that they might be correlated with the results of uniaxial mechanical constant rate tests. In logarithmic coordinates there is a linear relationship between the stress and failure time. A similar linear shape is obtained for the ultimate strength dependence on reduced time.

Mathematical form of the cumulative damage law (eq. 17) for the composite propellant marked as $\mathrm{KRG}-704[25,26]$, based on HTPB, is as follow:

$$
\begin{gathered}
\log \sigma=C+D \cdot \log \left(\frac{t_{f}}{a_{T}}\right) \\
\log \sigma=0,981-0,161 \cdot \log \left(\xi_{f}\right)
\end{gathered}
$$

\section{$\xi_{f} \quad$ - Reduced time to failure}

For two batches of the same propellant composition, complete mechanical characterization was performed, by uniaxial tensile tests at different temperatures and strain rates, according to the procedure $[3,8,11,12]$. The same shape is characteristic for the tensile strength "master curve" of the propellant $[1,15,22]$ :

$$
\log \sigma_{m} \cdot \frac{T_{0}}{T}=C+D \cdot \log \left(\frac{t}{a_{T}}\right)
$$

At the standard temperature $\left(T_{0}\right)$, factor $\left(T_{0} / T\right)=1$.

$$
\log \sigma_{m}=C+D \cdot \log \left(\frac{t}{a_{T}}\right)
$$

The following results were obtained:

$$
\begin{aligned}
& \log \sigma_{m}=1,111-0,128 \cdot \log (\xi) \\
& \log \sigma_{m}=1,137-0,140 \cdot \log (\xi)
\end{aligned}
$$

An overview of these two dependencies, tensile strength vs. reduced time $\sigma_{m}=f(\xi)$, and constant loads vs. failure times $\sigma=f\left(t_{f}\right)$ is presented in Fig. 10 .

In the papers from Blacksburg, Virginia [4, 27], a problem of cumulative damage is considered. Data were presented for a composite propellant, but the type of binder has not been indicated. Although data have not been explicitly shown, careful examination has provided the terms for "cumulative damage law" and the master curve of the ultimate strength:

$$
\begin{gathered}
\log \sigma_{m}=1,150-0,0857 \cdot \log (\xi) \\
\log \sigma=1,113-0,1143 \cdot \log (\xi)
\end{gathered}
$$

A comparative overview of these two dependencies is shown in Fig. 11.

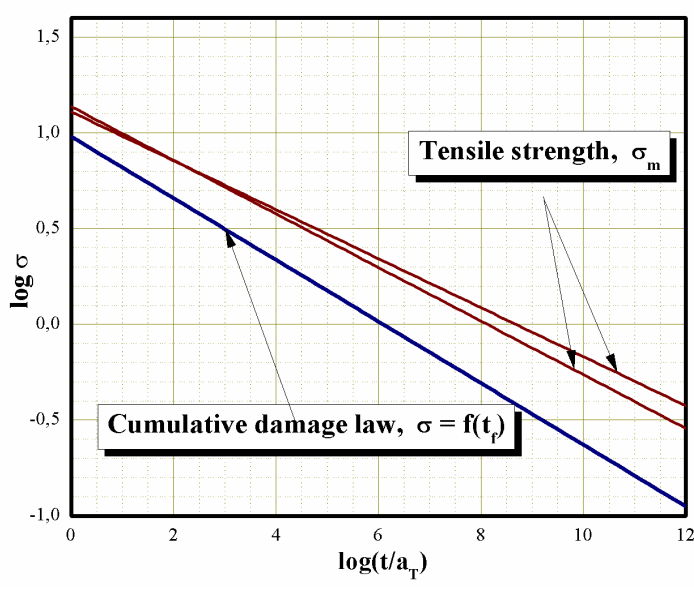

Figure 10. Tensile strength and cumulative damage law

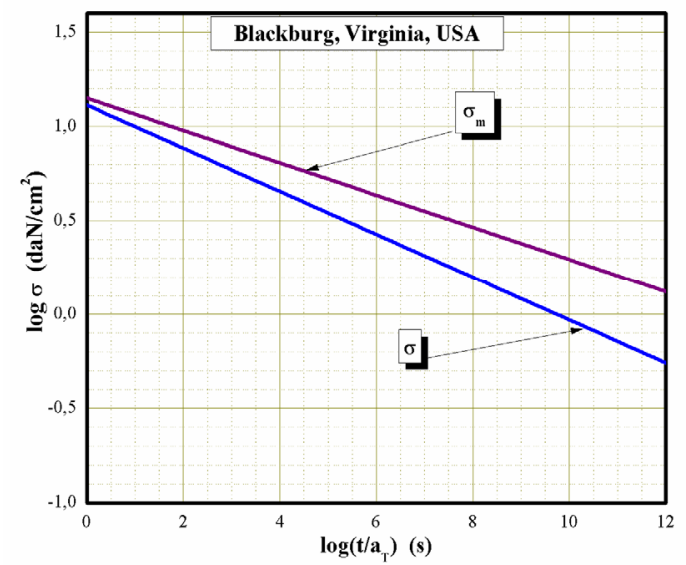

Figure 11. The ratio between $\left(\sigma_{m}\right)$ and $(\sigma)$ for the composition $[4,27]$

There is a similarity with the diagrams in Fig.10. The position of the tensile strength line is similar in relation to the line that represents cumulative damage law.

There is a correlation between cumulative damage law for a propellant and the tensile strength line [2]:

1. Cumulative damage line $(\sigma)$ is positioned to the left of the tensile strength line $\left(\sigma_{m}\right)$;

2. The slope of the cumulative damage line is slightly higher than the tensile strength line;

3. In the middle of the reduced-time scale $\left(t / a_{T}\right)$, for the values between 6 and 7, horizontal space between the two lines is approximately two decades of reduced time.

This correlation can be useful for a rocket motor designer to estimate the cumulative damage impact, at the design stage, when there is still no true data on the propellant properties.

\section{Conclusion}

Analysis [2, 8, 11] has shown that the impact of the cumulative damage cannot be neglected, regardless the widely accepted opinion that its influence is small, especially at the beginning of the propellant grain service life. Our practice tells us that it is quite possible for this impact to be great even in the initial period after production.

Careful design can reduce the impact of cumulative damage. During the design of the case bonded propellant grain, the importance of structural analysis is of the same order as the interballistic analysis. Typically, propellant grain structural analysis is carried out according to the principles of elastic analysis, but to include viscoelastic properties and their dependence on temperature and strain rate. This analysis often neglects a hidden 
phenomenon that, immediately after grain production, is almost imperceptible, but later it can lead to the failure. This is the occurrence of cumulative damage due to cyclic load effects.

A small number of authors are considering this phenomenon because they believe that intensity of cumulative damage is low, even after a very long time of storage and cyclic loads action.

Our experience suggests that it is quite possible for the impact of cyclic loads to be very large, soon after production. It depends not only on external loads but also on the propellant modulus, strength and allowable strain, geometric parameters of the grain and physical properties of the propellant and the motor chamber.

Proper choice of propellant composition, the grain shape and the material of the chamber, can reduce the negative effect of cyclic loads and cumulative damage.

Statistical approach can determine the probability of failure due to cyclical loads, as well as the grain reliability. This method requires determining the cumulative damage law, but the longterm tests are needed to be carried out. However, our analysis has shown that it is possible to use one simple rule that allows shortening of the analysis process and acceptable results of the preliminary analysis.

\section{References}

[1] NASA: Solid propellant grain structural integrity analysis. NASA Space Vehicle Design Criteria SP-8073, 1973.

[2] GLIGORIJEVIĆ,N., ŽIVKOVIĆ,S., RODIĆ,V., SUBOTIĆ,S., GLIGORIJEVIĆ,I.: Effect of Cumulative Damage on Rocket Motor Service Life, 2015, J ENERG MATER.

[3] GLIGORIJEVIĆ,N., RODIĆ,V., ŽIVKOVIĆ,S., PAVKOVIĆ,B., NIKOLIĆ,M., KOZOMARA,S., $\quad$ SUBOTIĆ,S.: Mechanical Characterization of Composite Solid Rocket Propellant based on HTPB, HEM IND, 2016, Vol.70.

[4] HELLER,R.A., SINGH,M.P., ZIBDEH,H.: Environmental Effects on Cumulative Damage in Rocket Motors, Journal of Spacecraft and Rockets, 1985, Vol.22, No,2, pp.149-155.

[5] TORMEY,J.F., BRITTON,S.C.: Effect of Cyclic Loading on Solid Propellant Grain Structures, AIAA journal, 1963, No.8, Vol.1, pp.1763-1770.

[6] HELLER,R.A., SINGH,M.P.: Thermal Storage Life of SolidPropellant Motors. Journal of Spacecraft and Rockets, 1983, Vol.20, No.2, pp.144-149.

[7] ZIBDEH,H.S., HELLER,R.A.: Rocket Motor Service Life Calculations Based on the First Passage Method, Journal of Spacecraft and Rockets, 1989, Vol.26, No.4, pp.279-284.

[8] GLIGORIJEVIĆ,N., RODIĆ,V., JEREMIĆ,R., ŽIVKOVIĆ,S., SUBOTIĆ,S.: Structural Analysis Procedure for a Case Bonded Solid Rocket Propellant Grain, Scientific Technical Review, ISSN 18200206, 2011, Vol.61, No.1, pp.1-9.

[9] CERRI,S., BOHN,A.M., MENKE,K., GALFETTI,L.: Ageing Behavior of HTPB Based Rocket Propellant Formulations. Central European Journal of Energetic Materials, 2009, 6(2), pp.149-165.

[10] SHIANG-WOEI,C.: A study of loading history effect for thermoviscoelastic solid propellant grains, Computers and Structures,
2000, Vol.77, No.6, pp.735-745.

[11] GLIGORIJEVIĆ,N.: Istraživanje pouzdanosti i veka upotrebe raketnih motora sa čvrstom pogonskom materijom (Solid propellant rocket motor reliability and service life research), Ph.D. Dissertation, Military Academy, Belgrade, Serbia (2010).

[12] GLIGORIJEVIĆ,N., etc.: Solid propellant rocket motors - selected topics, Belgrade, MTI\&Media center „Odbrana“, ISBN 978-86-8112363-8, 2013, ID 199479052

[13] MINER,M.A.: Cumulative Damage in Fatigue. Journal of Applied Mechanics, 1945, Vol.12, pp.A159-A164.

[14] RHMZ-(Serbian Republic Hydrometeorological Service): 2008. Meteo Yearbook 1, Climatological data. www.hidmet.gov.rs.

[15] WILLIAMS,M.L., BLATZ,P.J., SCHAPERY,R.A.: Fundamental Studies Relating to Systems Analysis of Solid Propellants, Final report GALCIT 101, Guggenheim Aeronautical Lab., Pasadena, California, 1961.

[16] NASA: Solid propellant grain design and internal ballistics. NASA Space Vehicle Design Criteria SP-8076, 1972.

[17] МОСКВИТИН,В.В.: Сопротивление вјазко-упругих материалов, Наука, Москва, 1972.

[18] FITZGERALD,J.E., HUFFERD,W.L.: Handbook for the Engineering Structural Analysis of solid Propellants, CPIA publication 214, 1971.

[19] Structural Assessment of Solid Propellant Grains, Agard Advisory Report 350. ISBN 92-836-1063-6, 1997.

[20] GLIGORIJEVIĆ,N., JEREMIĆ,R., ŽIVKOVIĆ,S., RODIĆ,V., DIMITRIJEVIĆ,R., SUBOTIĆ,S.: Probabilistic Methodology for Solid Propellant Case-bonded Grain Reliability Estimation, $4^{\text {th }}$ International Scientific Conference OTEH 2011, 06-07. October 2011, Belgrade, SERBIA, ISBN 978-86-81123-50-8.

[21] WILLIAMS,M.L.: Structural Analysis of Viscoelastic Materials, AIAA Journal, 1964, May: pp.785-798, Calif. Institute of Technology, Pasadena, California.

[22] LANDEL,R.F., SMITH,T.L.: Viscoelastic Properties of Rubberlike Composite Propellants and Filled Elastomers, ARS Journal, 1960, Vol.31, No5, pp.599-608.

[23] WILLIAMS,M.L., LANDEL,R.F., FERRY,J.D.: The Temperature Dependence of Relaxation Mechanisms in Amorphous Polymers and Other Glass-forming Liquids, J. Am. Chem. Soc., 1955, 77 (14), pp.3701-3707, DOI: 10.1021/ja01619a008.

[24] Liu,C.T.: Cumulative Damage and Crack Growth in Solid Propellant, Media Pentagon Report No A486323, 1997.

[25] RODIĆ,V., GLIGORIJEVIĆ,N.: Uniaxial mechanical characterization of the KRG-704 composite rocket propellant, Technical report, VTI004-01-0555, VTI, Belgrade, Nov. 2009.

[26] GLIGORIJEVIĆ,N.: Određivanje zakona izdržljivosti HTPB kompozitnog raketnog goriva pri dejstvu konstantnih opterećenja (Cumulative damage law estimation for a HTPB composite rocket propellant), Report VTI-003-01-0029, VTI, Belgrade, Dec. 2010.

[27] HELlER,R.A., KAMAT,M.P., SINGH,M.P.: Probability of Solid Propellant Motor Failure Due to Environmental Temperatures, Journal of Spacecraft and Rockets, 1979, Vol.16, No3.

\title{
Uticaj cikličnih opterećenja na strukturna oštećenja pogonskih punjenja raketnih motora
}

\begin{abstract}
Pogonsko punjenje raketnog motora, direktno liveno ili vezano za komoru ili čvrstu oblogu, izloženo je različitim opterećenjima tokom veka upotrebe. Raketno gorivo je viskoelastični materijal, čije mehaničke osobine značajno zavise od temperature i brzine deformacije. Dejstvo cikličnih opterećenja, pre svega termičkih, na raketni motor na skladištu, može da izazove neželjena oštećenja pogonskog punjenja. Vremenom, posle dugog skladištenja, nagomilana oštećenja mogu da porastu toliko da izazovu lom punjenja. Jedan od načina da se proceni ova pojava je da se odredi zakon akumulacije oštećenja. U ovom primeru, zakon je određen za jedan sastav kompozitnog raketnog goriva na bazi hidroksi-terminiranog polibutadiena (HTPB), izlaganjem njegovih uzoraka različitim dugotrajnim naprezanjima. Pomoću ovog zakona moguće je izračunati verovatnoću loma i vremensku promenu strukturne pouzdanosti pogonskog punjenja, sa ciljem da se proceni vek upotrebe. Pored toga, analiza je pokazala da postoji moguća korelacija zakona akumulacije oštećenja i zatezne čvrstoće. Ova činjenica može da se iskoristi umesto izvođenja dugotrajnog eksperimenta kojim se precizno određuje zakon akumulacije oštećenja.
\end{abstract}

